\title{
Remediation of heavy metal contaminated ecosystem: an overview on technology advancement
}

\author{
A. Singh $\cdot$ S. M. Prasad
}

Received: 17 May 2013/Revised: 31 December 2013/Accepted: 5 March 2014/Published online: 9 April 2014

(C) Islamic Azad University (IAU) 2014

\begin{abstract}
The issue of heavy metal pollution is very much concerned because of their toxicity for plant, animal and human beings and their lack of biodegradability. Excess concentrations of heavy metals have adverse effects on plant metabolic activities hence affect the food production, quantitatively and qualitatively. Heavy metal when reaches human tissues through various absorption pathways such as direct ingestion, dermal contact, diet through the soil-food chain, inhalation and oral intake may seriously affect their health. Therefore, several management practices are being applied to minimize metal toxicity by attenuating the availability of metal to the plants. Some of the traditional methods are either extremely costly or they are simply applied to isolate contaminated site. The biology-based technology like use of hypermetal accumulator plants occurring naturally or created by transgenic technology, in recent years draws great attention to remediate heavy metal contamination. Recently, applications of nanoparticle for metal remediation are also attracting great research interest due to their exceptional adsorption and mechanical properties and unique electrical property, highly chemical stability, and large specific surface area. Thus, the present review deals with different management approaches to reduce level of metal contamination in soil and finally to the food chain.
\end{abstract}

Keywords Heavy metal - Toxicity · Remediation · Nanotechnology

\footnotetext{
A. Singh · S. M. Prasad ( $\square)$

Ranjan Plant Physiology and Biochemistry Laboratory,

Department of Botany, University of Allahabad,

Allahabad 211002, India

e-mail: sheomohanp@yahoo.co.in
}

\section{Introduction}

Environmental pollution occurs due to industrialization and extraction of natural resources in large scale, and it is responsible for degradation of environmental health. Among all kinds of pollution, heavy metals make a significant contribution to the environmental pollution (NedelKoska and Doran 2000). The metal present in soil-plant system can easily enter into food chain and also cause risk for humans, animals, plants and whole environment of our modern society (Farouk et al. 2011).

Heavy metals are listed as priority pollutants by the United States Environmental Protection Agency (UEPA). There are more than 70,000 chemicals in use in the world (Cairns et al. 1988). For the level of toxicity, lead, mercury, arsenic and cadmium are ranked first, second, third, and sixth, respectively, in the list of US Agency for Toxic Substances and Disease Registry (ATSDR), which generally lists all hazards present in toxic waste sites on the basis of their prevalence and severity of toxicity. The problem of heavy metal pollution is emerging as a matter of concern at local, regional and global scales. In aquatic and terrestrial ecosystems, high levels of heavy metals can act as ecological toxins (Nazemi 2012; Veschasit et al. 2012). In the present scenario, anthropogenic inputs of metals exceed natural inputs.

Data of central pollution control board (CPCB 2011) show that Gujarat, Maharashtra and Andhra Pradesh contribute $80 \%$ of hazardous waste (including heavy metals) in India. Apart from industries, roadways and automobiles contribute substantially to environmental burden of heavy metals since particulate matters in traffic emissions include heavy metals like lead, cadmium and arsenic (Onat et al. 2013). Application of sewage sludge in agricultural fields resulted in the accumulation of heavy metals in the soil and 
consequently to plants (Arvas et al. 2013; Nogueira et al. 2013). The concentrations of trace metals in sewage water and sludge samples from River Kubanni drainage basin in Zaria City, Nigeria were studied by Adamu et al. (2013). Groundwater can be contaminated with metals directly by infiltration of leachate from land disposal of solid wastes, liquid sewage or sewage sludge, leachate from mine tailings and other mining wastes, deep-well disposal of liquid wastes, seepage from industrial waste lagoons or from other spills and leaks from industrial metal processing facilities (e.g., steel plants, plating shops, etc.).

Total extractable trace metals $\left(\mathrm{mg} \mathrm{kg}^{-1}\right)$ in sewage sludge were 403.3, 184.2, 303.4, 129.0 and 19.7 for $\mathrm{Zn}, \mathrm{Ni}$, $\mathrm{Cu}, \mathrm{Pb}$ and $\mathrm{Cd}$, respectively (Adamu et al. 2013). In recent years, use of energy-saving compressed fluorescent lamp (CFL) bulbs has gone up enormously. Hence, the production of CFL bulbs has increased from 19 million in 2002 to 500 million in 2010. Each bulb contains $3-12 \mathrm{mg}$ of mercury. With no system to recover these bulbs and safe disposal, it may prove to be a major health hazard.

The problem of heavy metal pollution is continuously worsening due to a series of human activities, leading to an intensification of research dealing with the phytotoxicity of these contaminants and with mechanisms used by plants to counter their detrimental effects (Rascio and Navari-Izzo 2011). Transfer of toxic elements to human food chain is a concrete danger that has to be faced in the near future. Living organisms require varying amounts of few heavy metals. Iron, cobalt, copper, manganese, molybdenum and zinc are required by humans in trace amounts. All metals are toxic at higher concentrations (Singh et al. 2011). Other heavy metals such as mercury, plutonium, arsenic, cadmium and lead are toxic metals that have no known vital or beneficial effect on organisms, and their accumulation over time in the bodies of animals can cause serious illness. Heavy metals disrupt metabolic functions in human beings. Excess accumulation disrupts the function of vital organs and glands such as heart, brain, kidneys, bone, liver, etc. These metals displace the vital nutritional minerals from their original place, and hinder their biological function. These metals can enter into our body through consumption of foods, beverages, skin exposure and inhaled air. Among different heavy metals, chronic exposure to low doses of cancer-causing heavy metals may induce many types of cancer. Park et al. (2004) found an increased lifetime risk of lung cancer death resulted from occupational exposure to dusts and mists containing hexavalent chromium. The risk of postmenopausal breast cancer may increase due to consumption of cadmium-contaminated rice and other foods (Hiroaki et al. 2014). Acute and chronic exposure of arsenic could also cause numerous human health problems. These included dermal, respiratory, cardiovascular, gastrointestinal, hematological, hepatic, renal, neurological, developmental, reproductive, immunological, genotoxic, mutagenic and carcinogenic effects (such as liver cancer) (Lin et al. 2013).

So, there is a need of technology to clean environment up to safer limit with suitable techniques, which must be easy to handle, cost-effective and feasible. A range of technologies is available for remediation of metals-contaminated soil. The comparison of different kind of technologies is given in Table 1. General approaches to remediation of metal contamination include isolation, immobilization, toxicity reduction, physical separation and extraction. These general approaches can be used for many types of contaminants but the specific technology selected for treatment of a metals-contaminated site will depend on form of the contamination and other site-specific characteristics.

The present review covers the whole scenario of metal contamination and its effects on plant responses. It also includes remediation technologies which can be easily applied in the metal-contaminated areas.

\section{Metal toxicity through food chain contamination (soil $\rightarrow$ plant $\rightarrow$ consumer)}

Due to continuous industrialization and urbanization activities, heavy metal pollution becomes a major cause of environmental degradation. Different countries showed different level of metal contamination. The South and Southeast Asian countries, like Peninsular Malaysia, Vietnam, India, Thailand, Philippines, Indonesia, Bangladesh and Pakistan have taken much care regarding monitoring of the contamination of agricultural soils and crops by heavy metals.

Kapungwe (2013) has studied metal $(\mathrm{Co}, \mathrm{Cr}, \mathrm{Cu}, \mathrm{Pb}$ and $\mathrm{Ni})$ contamination of water, soils and crops at two wastewater-irrigated study sites (New Farm Extension in $\mathrm{Mu}-$ fulira and Chilumba Gardens in Kafue) in Zambia. The results indicated that heavy metals were present in the water, soil and crops at the two study sites and exceeded acceptable limits. Zeid et al. (2013) reported that in agricultural research center of Giza, Egypt, wastewater usage for irrigation has resulted metal accumulation in soils and plants beyond maximum permissible limits, for livestock consumption.

Among different metals, it was suggested that $\mathrm{Cd}$ would be the most mobile element in the soil and more available to crop. Industrial emissions of contaminant to the atmosphere which is finally deposited on soil or dumping of industrial wastes on disposal land may cause problem in the environment beyond limit. In India, many urban and dense cities with significant industrial waste generation have been found to have contaminated soil. 
Table 1 Comparative analysis of different methods used for metal remediation

\begin{tabular}{|c|c|c|c|c|c|}
\hline & Way of treatments & $\begin{array}{l}\text { Detail and result of } \\
\text { treatment }\end{array}$ & Advantage & Disadvantage & References \\
\hline \multirow[t]{2}{*}{ Physical } & Mechanical separation & $\begin{array}{l}\text { Reduction in metal } \\
\text { contamination in soil }\end{array}$ & $\begin{array}{l}\text { Significant volume } \\
\text { reduction in } \\
\text { contaminated soil }\end{array}$ & $\begin{array}{l}\text { It could not applied in case } \\
\text { of homogenous } \\
\text { distribution of pollutants } \\
\text { in soil }\end{array}$ & $\begin{array}{l}\text { Ottosen and } \\
\text { Jensen } \\
(2005)\end{array}$ \\
\hline & Electro kinetic remediation & $\begin{array}{l}\text { Reduction in metal } \\
\text { contamination in soil }\end{array}$ & $\begin{array}{l}\text { This method is applicable } \\
\text { to different metals }\end{array}$ & $\begin{array}{l}\text { Any heterogeneity of the } \\
\text { soil body decreases the } \\
\text { effectiveness of the } \\
\text { method and considerable } \\
\text { acidification of the } \\
\text { remediated soil is a side } \\
\text { effect of this method }\end{array}$ & $\begin{array}{l}\text { Tahmasbian } \\
\text { and } \\
\text { Nasrazadani } \\
\text { (2012) }\end{array}$ \\
\hline \multirow[t]{2}{*}{ Chemical } & $\begin{array}{l}\text { Soil washing (ex situ } \\
\text { technique) }\end{array}$ & $\begin{array}{l}\text { For removing inorganic } \\
\text { contamination, such as } \\
\text { heavy metals, radio- } \\
\text { nuclides, toxic anions } \\
\text { and others }\end{array}$ & $\begin{array}{l}\text { Highly effective method } \\
\text { for cleaning up strongly } \\
\text { contaminated soils }\end{array}$ & $\begin{array}{l}\text { High costs of construction } \\
\text { of the cleaning } \\
\text { installation and } \\
\text { utilization }\end{array}$ & $\begin{array}{l}\text { Wuana and } \\
\text { Okieimen } \\
(2011)\end{array}$ \\
\hline & $\begin{array}{l}\text { Soil flushing (in situ } \\
\text { technique) }\end{array}$ & $\begin{array}{l}\text { For removing inorganic } \\
\text { contamination, such as } \\
\text { heavy metals, radio- } \\
\text { nuclides, toxic anions } \\
\text { and others }\end{array}$ & $\begin{array}{l}\text { Relatively low invasive } \\
\text { method }\end{array}$ & $\begin{array}{l}\text { A large amount of liquid } \\
\text { and semi-liquid wastes } \\
\text { are generated }\end{array}$ & $\begin{array}{l}\text { Wuana and } \\
\text { Okieimen } \\
(2011)\end{array}$ \\
\hline \multirow[t]{3}{*}{ Soil amendments } & Addition of lime & $\begin{array}{l}\text { Reduce the mobility of } \mathrm{Cd} \text {, } \\
\mathrm{Cu}, \mathrm{Ni}, \mathrm{Pb}, \mathrm{Zn}\end{array}$ & & $\begin{array}{l}\text { Changes the physico- } \\
\text { chemical properties of } \\
\text { soil }\end{array}$ & $\begin{array}{l}\text { Guo et al. } \\
\text { (2006) }\end{array}$ \\
\hline & $\begin{array}{l}\text { Addition of chelating } \\
\text { agents (ethylene diamine } \\
\text { tetra acetic acid; EDTA) }\end{array}$ & $\begin{array}{l}\text { Reduce the mobility of } \mathrm{Pb} \\
\text { and } \mathrm{Cu}\end{array}$ & & & $\begin{array}{l}\text { Sukumara } \\
\text { et al. (2012) }\end{array}$ \\
\hline & $\begin{array}{l}\text { Addition of biological } \\
\text { products } \\
\text { a. Bark saw dust } \\
\text { b. Cattle manure } \\
\text { c. Rice hulls }\end{array}$ & $\begin{array}{l}\text { a. Reduce the mobility of } \\
\mathrm{Cd}, \mathrm{Pb}, \mathrm{Hg}, \mathrm{Cu} \\
\text { b. Reduce the mobility of } \\
\mathrm{Cd} \\
\text { c. Reduce the mobility of } \\
\mathrm{Cd}, \mathrm{Cr} \text { and } \mathrm{Pb}\end{array}$ & $\begin{array}{l}\text { Increases the binding } \\
\text { property of soil with } \\
\text { metals }\end{array}$ & $\begin{array}{l}\text { Some physico-chemical } \\
\text { properties of soil is } \\
\text { changed }\end{array}$ & $\begin{array}{l}\text { Nagh and } \\
\text { Hanafiah } \\
\text { (2008) } \\
\text { Angelova } \\
\text { et al. (2010) }\end{array}$ \\
\hline $\begin{array}{l}\text { Biological } \\
\text { method }\end{array}$ & By using micro-organism & $\begin{array}{l}\text { Removes the metal } \\
\text { contaminants as a result } \\
\text { of sorption and/or } \\
\text { transformation }\end{array}$ & $\begin{array}{l}\text { Removes the } \\
\text { contaminants as a result } \\
\text { of sorption and/or } \\
\text { transformation. Soil } \\
\text { retains its properties } \\
\text { and could be replaced } \\
\text { on the reclaimed site }\end{array}$ & $\begin{array}{l}\text { Construction of a special } \\
\text { installation is required. } \\
\text { Large amounts of wastes } \\
\text { (solid, liquid) are } \\
\text { generated }\end{array}$ & \\
\hline Phytoremediation & $\begin{array}{l}\text { a. Phytostabilisation } \\
\text { b. Phytoextraction } \\
\text { c. Phytovolatilization }\end{array}$ & $\begin{array}{l}\text { Contaminants are absorbed } \\
\text { into roots and } \\
\text { precipitated in the roots' } \\
\text { area contaminants are } \\
\text { picked up by the roots of } \\
\text { plants and transported to } \\
\text { their overground parts, } \\
\text { and then removed } \\
\text { together with the crops. } \\
\text { Uptake and transpiration } \\
\text { of such elements by } \\
\text { plants. The element is } \\
\text { taken up by plant roots, } \\
\text { transported through the } \\
\text { xylem and is finally } \\
\text { released to the } \\
\text { atmosphere from cellular } \\
\text { tissues (evaporates or } \\
\text { vaporizes) }\end{array}$ & $\begin{array}{l}\text { Low-cost method. } \\
\text { Practically no side } \\
\text { effects } \\
\text { Relatively low costs } \\
\text { The method is } \\
\text { environmentally } \\
\text { friendly }\end{array}$ & $\begin{array}{l}\text { Contaminants are not } \\
\text { removed from the soil } \\
\text { but only immobilized } \\
\text { Plants and soil require } \\
\text { long-term monitoring }\end{array}$ & $\begin{array}{l}\text { Fasaei (2012) } \\
\text { Jiang et al. } \\
(2010) \\
\text { Rahimi et al. } \\
(2013)\end{array}$ \\
\hline
\end{tabular}


Table 1 continued

\begin{tabular}{|c|c|c|c|c|c|}
\hline & Way of treatments & $\begin{array}{l}\text { Detail and result of } \\
\text { treatment }\end{array}$ & Advantage & Disadvantage & References \\
\hline $\begin{array}{l}\text { Biotechnological } \\
\text { approach }\end{array}$ & By using genetic tools & $\begin{array}{l}\text { Transgenic plants removed } \\
\text { up to } 6 \% \mathrm{Zn} \text { and } 25 \% \\
\mathrm{Cd} \text { of the soil metal; } \\
\text { Tobacco callus showed } \\
\text { more resistance to } \\
\text { methyl mercury } \\
\left(\mathrm{CH} 3 \mathrm{Hg}^{+}\right) \text {and } \\
\text { accumulated more } \\
\text { mercury from } \mathrm{CH} 3 \mathrm{Hg}^{+}- \\
\text {containing medium }\end{array}$ & $\begin{array}{l}\text { Transgenic plants might } \\
\text { be able to contribute to } \\
\text { the wider and safer } \\
\text { application of } \\
\text { phytoremediation }\end{array}$ & Not studied & $\begin{array}{l}\text { Kupper and } \\
\text { Kochian } \\
(2010) ; \\
\text { Nagata et al. } \\
(2010)\end{array}$ \\
\hline $\begin{array}{l}\text { Nanotechnology } \\
\text { approach }\end{array}$ & $\begin{array}{l}\text { Use of particles with at } \\
\text { least one dimension in } \\
\text { the range of } 1-100 \mathrm{~nm} \text {, } \\
\text { to affect the mobility, } \\
\text { toxicity and/or } \\
\text { bioavailability of } \\
\text { contaminants in their } \\
\text { natural environment }\end{array}$ & $\begin{array}{l}\text { Use of nano-ZVI, } \\
\text { bimetallic nanoparticles, } \\
\text { and emulsified zero- } \\
\text { valent nanoparticle } \\
\text { reduces the metal } \\
\text { contamination from soil } \\
\text { and groundwater }\end{array}$ & $\begin{array}{l}\text { Very efficient for } \\
\text { removing the metal }\end{array}$ & Not studied & $\begin{array}{l}\text { Xiong et al. } \\
\text { (2009); } \\
\text { Agarwal and } \\
\text { Joshi (2010) }\end{array}$ \\
\hline
\end{tabular}

The levels of $\mathrm{Pb}, \mathrm{As}, \mathrm{Cr}, \mathrm{Cd}$ and $\mathrm{Zn}$ were determined in vegetables: leek (Allium ampeloprasum), coriander (Coriandrum sativum), parsley (Petroselinum crispum), cress (Lepidium sativum), basil (Ocimum basilicum), radish leaf (Raphanus sativus) and beet leaf (Beta vulgaris) collected from North East of Iran (Nazemi 2012). The heavy metal concentration in vegetable samples showed a range of $\mathrm{Cr}$ (2.4-5.88), Zn (54.27-170.23), As (1.92-5.49), Cd (1.94-2.43) and $\mathrm{Pb}(18.48-21.3)$ in $\mathrm{mg} \mathrm{kg}^{-1}$. The study showed that vegetables grown in this region are a health hazard for human consumption (Nazemi 2012). The accumulation of $\mathrm{As}, \mathrm{Cd}, \mathrm{Cr}, \mathrm{Pb}$ and $\mathrm{Zn}$ in soils and vegetables in vicinity of Enyigba lead mine was observed by Wilberforce and Nwabue (2013), in the edible vegetables such as Telfaria occidentalis (fluted pumpkin); Talinum triangulare(water leaf); Amaranthus hybridus (Amaranth or pigweed); Vernonia amygdalina (bitter leaf) and Solmun nigrum (garden egg leaf). The results revealed that heavy metal values $\left(\mathrm{mg} \mathrm{kg}^{-1}\right)$ in vegetable ranged from 0.035 to $0.400,0.001$ to $0.01,0.023$ to $0.273,0.105$ to 0.826 and 0.016 to 0.174 for As, $\mathrm{Cd}, \mathrm{Cr}, \mathrm{Pb}$ and $\mathrm{Zn}$, respectively. The levels of arsenic and lead in bitter leaf and garden egg leaf exceeded WHO maximum limit. Karimi et al. (2013) have collected plant and soil samples from uncontaminated and contaminated sites of the Dashkasan mining area, western Iran. Total and water-soluble arsenic in the soil ranged from 7 to 795 and from 0.007 to $2.32 \mathrm{mg} \mathrm{kg}^{-1}$, respectively. The highest arsenic concentration in soil was found at the ore dressing area (up to $1,180 \mathrm{mg} \mathrm{kg}^{-1}$ ) and lowest at an uncontaminated area (up to $11 \mathrm{mg} \mathrm{kg}^{-1}$ ). Among all collected plants, the highest arsenic concentrations were found in Hyoscyamus kurdicus Bornm (up to $205 \mathrm{mg} \mathrm{kg}^{-1}$ ) and Helichrysum oligocephalum DC (up to $162 \mathrm{mg} \mathrm{kg}^{-1}$ ). These two accumulator species could have potential for soil cleanup by phytoextraction.
A geochemical investigation has been carried out in and around the Patancheru industrial development area of Andhra Pradesh to find out the extent of chemical pollution in the soil by Govil et al. (2001). It was found that contaminated soil showed two to three times higher level of toxic elements than normal and some metals like $\mathrm{Cr}, \mathrm{V}, \mathrm{Fe}$, $\mathrm{As}, \mathrm{Cd}, \mathrm{Se}, \mathrm{Ba}, \mathrm{Zn}, \mathrm{Sr}$, Mo and $\mathrm{Cu}$ were found to be present above normal distribution in the soil. Singh et al. (2002) reported that stream sediments from Lucknow, Kanpur, Delhi and Agra in India were classified as highly polluted to dangerous sediments. The soil samples were collected from Pali Industrial area, present in the western state of Rajasthan (Krishna and Govil 2004). The result showed that soil in the study area is significantly contaminated with high concentrations of heavy elements like $\mathrm{Pb}, \mathrm{Cr}, \mathrm{Cu}, \mathrm{Zn}$, $\mathrm{Sr}$ and V. Similar study was done by Lokeshwari and Chandrappa (2006) around the city of Bangalore to assess heavy metal contamination of vegetation and soil due to irrigation with sewage-fed lake water on agricultural land. The results showed significant amount of heavy metals, above the Indian Standard limits in both the soil as well as the vegetation samples. In 2007, soil samples were collected from the industrial area of Surat city, present in the western state of Gujarat by Krishna and Govil (2007). It was found that soil in the study area is significantly contaminated with high concentrations of heavy elements like $\mathrm{Ba}, \mathrm{Cu}, \mathrm{Cr}, \mathrm{Co}, \mathrm{Ni}, \mathrm{Sr}, \mathrm{V}$ and $\mathrm{Zn}$. Metal contamination is also studied near wastewater-irrigated sites of Varanasi city (Sharma et al. 2009). In this study, soil samples of major irrigation sites in sub-urban areas of Varanasi were taken and analyzed for heavy metal contamination. Samples of irrigation water and portion of vegetables being grown were also collected. Apart from concentration of $\mathrm{Cd}$, rest of the heavy metals was present within the Indian standards. 
Singh et al. (2010) have also reported that concentration of $\mathrm{Cd}, \mathrm{Pb}$ and $\mathrm{Ni}$ is above safe limit in the vegetables collected from wastewater-irrigated sites of Dinapur sites of Varanasi city.

Soil to plant transfer is the major component of animal and human exposure to heavy metals through the food. It was shown by Fig. 1. Chronic intakes of heavy metals have damaging effects on human beings and other animals (John and Andrew 2011; Liu et al. 2013). Jolly et al. (2013) have investigated the concentration of $\mathrm{Si}, \mathrm{Ba}, \mathrm{K}, \mathrm{Ca}, \mathrm{Mg} \mathrm{Fe}, \mathrm{Sc}$, $\mathrm{V}, \mathrm{Cr}, \mathrm{Cu}, \mathrm{Zn}, \mathrm{As}, \mathrm{Mn}, \mathrm{Co}, \mathrm{Ni}, \mathrm{Se}, \mathrm{Sr}, \mathrm{Mo}$ and $\mathrm{Cd}$ metals in agricultural soil and vegetables collected from agricultural land at Ruppur area of Pabna District of Bangladesh and also evaluated the possible health risks to human body through food chain transfer. Among all metals, the daily intake of $\mathrm{Cd}$ was estimated $0.178 \mathrm{mg} / \mathrm{g}$ and $\mathrm{HQ}$ value for $\mathrm{Cd}$ calculated was 2.543 , which is much higher than the safe value. $\mathrm{Cd}$ is a very toxic element, its long-term exposure to lower level leads to build up in kidneys and possible kidney disease, lung damage and fragile bones.

Harmanescu et al. (2011) have calculated daily metal intake for normal daily intake consumption of contaminated vegetable collected from copper and lead extraction and processing industry in Banat country, south West part of Romania. They have found that value of daily metal intake for $\mathrm{Fe}, \mathrm{Mn}$ and $\mathrm{Pb}$ exceeded the upper tolerable daily intake.

Heavy metals were analyzed by Jan et al. (2011) in different food crops, milk and meat, and blood samples collected from different age group subjects such as children (1-12 years), adolescent (12-18 years), adults (18-45 years) and old age (above 45 and 55 years for males and females, respectively) from polluted and relatively less polluted areas. The results revealed that consumption of contaminated food crops, meat and milk have significantly increased concentrations of selected metals in the human blood. $\mathrm{Cu}, \mathrm{Zn}$ and $\mathrm{Mn}$ concentrations were significantly higher $(p<0.05)$ in the blood samples collected from the polluted area as compared to control area. Old people had accumulated high concentrations of metals as compared to the younger ones within the same area.

Javed and Usmani (2013) examined the contamination of rivulet situated at Kasimpur, Aligarh $\left(27.218^{\circ} \mathrm{N} ; 79.378^{\circ} \mathrm{E}\right)$. It receives the wastewater of Harduaganj Thermal Power Plant (HTPS) containing fly ash and heavy metals. Among the heavy metals estimated in the rivulet water, $\mathrm{Fe}$ $\left(8.71 \mathrm{mgL}^{-1}\right)$ was present in the highest concentration followed by $\mathrm{Cu}\left(0.86 \mathrm{mgL}^{-1}\right), \mathrm{Zn}\left(0.30 \mathrm{mgL}^{-1}\right), \mathrm{Mn}$ $\left(0.21 \mathrm{mgL}^{-1}\right), \mathrm{Ni}\left(0.12 \mathrm{mgL}^{-1}\right)$, Co $\left(0.11 \mathrm{mgL}^{-1}\right)$ and $\mathrm{Cr}$ $\left(0.10 \mathrm{mgL}^{-1}\right)$. Bioaccumulation of these heavy metals was detected in tissues such as gills, liver, kidney, muscle and integument of the fish Mastacembelus armatus. Accumulation of $\mathrm{Fe}\left(213.29-2,601.49 \mathrm{mg} \mathrm{kg}^{-1}\right)$ was highest in all the organs. Liver was the most influenced organ and integument had the least metal load. The accumulation of $\mathrm{Fe}, \mathrm{Zn}, \mathrm{Cu}$ and $\mathrm{Mn}$ observed in the tissues was above the values recommended by FAO/WHO (Javed and Usmani 2013).
Fig. 1 Metal absorption process from water, soil and air to food chain and finally to humans

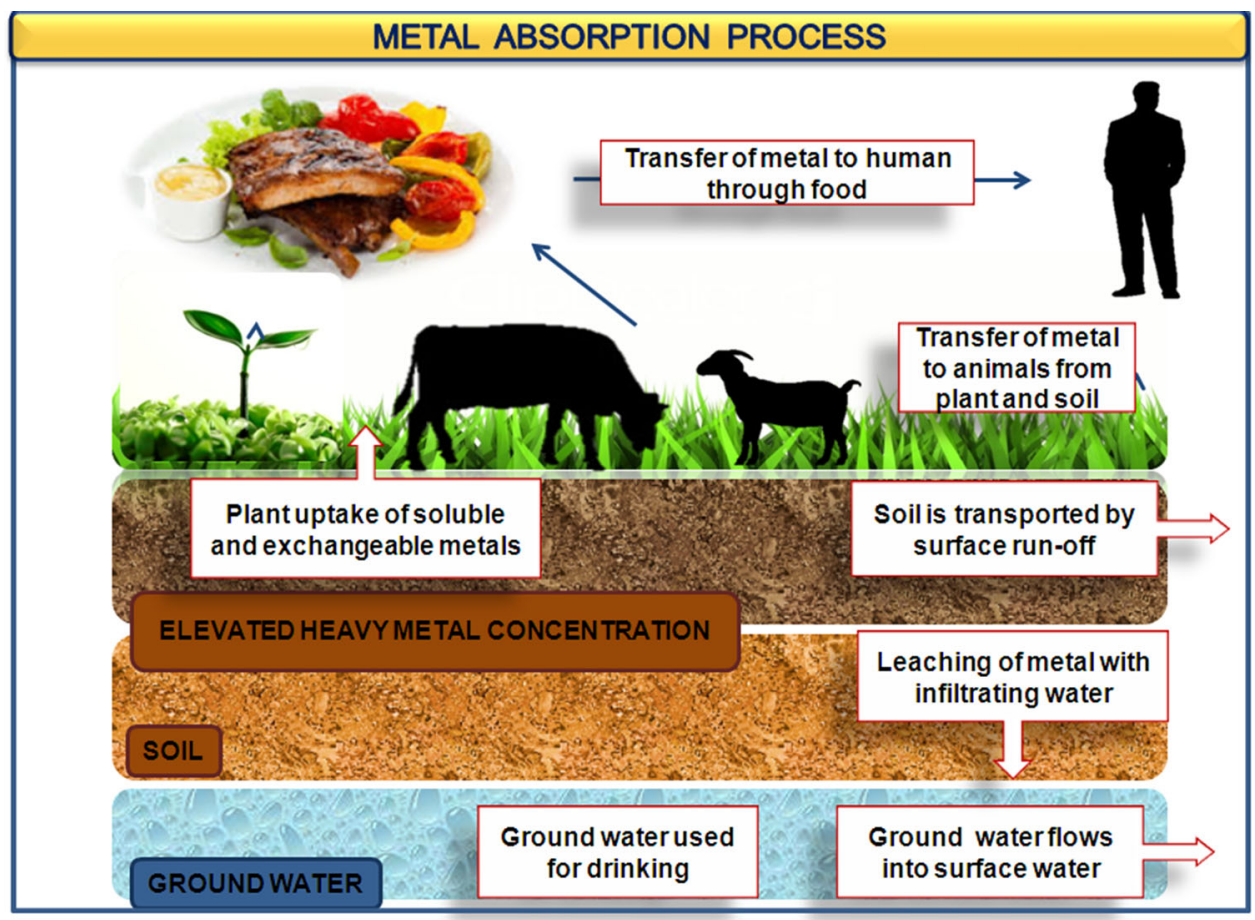


Entrapment strategy to reduce metal availability from soil

\section{By using chelating materials}

The chelating agents have a property to desorb toxic metals from soil solid phases by forming strong water-soluble complexes. After complex formation, it can be removed from the soil by plants through enhanced phytoextraction or by using soil washing techniques. In the process of phytoextraction with the help of chelant, it was applied to the soils. First, chelant can desorb metals from the soil matrix, and the mobilized metals move to rhizosphere for uptake by plant roots (Tahmasbian and Sinegani 2013). The amounts of bio-available metals in soil solution are mainly determined by the properties of the soil and applied chelant (Tandy et al. 2004; Luo et al. 2005). In order to reduce discharge of metal chelants into ground water and for reducing impact of chelant on soil micro-organisms, its selection, its amount and process of their application are important (Evangelou et al. 2007; Luo et al. 2007). Sukumara et al. (2012) have observed that Ethylene Diamine Tetra Acetic acid (EDTA) is one of the most powerful and commonly used chelating agents, which forms complexes with many of metal contaminants within the natural environment. It was found that application of EDTA as chelating agent increases the efficiency of an emergent wetland plant species such as Typha sp. and floating wetland macrophytes like Pistia sp., Azolla sp., Lemna sp, Salvinia sp. and Eichhornia sp. in phytoremediation of lead and copper (Sukumara et al. 2012).

The conventional complexing agents have some undesired features such as their persistence or slow transformation in the environment, remobilization of toxic metal ions mainly from sediments and soils as well as radionuclides from radioactive waste are of great concern, therefore, their replacement and the use of chelating agents with improved biodegradability is necessary (Reinecke et al. 2000). It should be stressed that most of the aminoploycarboxylic acids (such as EDTA-ethylene diamine tetra acetic acid, IDA-iminodiacetic acid, DTPA-diethylenetriaminepentaacetic acid) are resistant to conventional biological and physicochemical methods. Luo et al. (2005) found that EDTA is more efficient than [S, S]EDDS (ethylenediamine disuccinic acid) in extraction of $\mathrm{Pb}$ and $\mathrm{Cd}$, but [S, S]-EDDS is more effective in the extraction of $\mathrm{Cu}$ and $\mathrm{Zn}$. It was found that combined application of EDTA and [S, S]-EDDS led to a higher level of efficiency (i.e., a synergy effect) in phytoextraction of $\mathrm{Cu}, \mathrm{Pb}, \mathrm{Zn}$ and $\mathrm{Cd}$ that could be obtained by the application of either chelant alone (Luo et al. 2005). Gupta and Sinha (2006) used five different metal extractants from different tannery sludge amendment. The result showed that metal extraction efficiency of each extractants was highest in EDTA followed by DTPA $>\mathrm{NH}_{4} \mathrm{NO}_{3}>\mathrm{NaNO}_{3}>\mathrm{CaCl}_{2}$. Dede et al. (2012) have done a pot experiment to investigate the influence of elemental sulfur, gypsum and chelating agent (ethylenediaminetetraacetic acid: EDTA) on copper, zinc, nickel, cadmium, chromium and lead uptake by Brassica juncea from sewage sludge. Sulfur addition acidified the sludge, which caused the $\mathrm{pH}$ decrease to 5.4 with an initial pH 6.7. Applications of EDTA and sulfur resulted in a considerable increase in copper and lead concentrations in the plant. The result showed that elemental sulfur will be more effective amendment for phytoextraction of heavy metals from sewage sludge.

\section{By using natural products}

To replace the conventional adsorbents now special attention has been focused on the use of natural sorbents as an alternative depending upon their availability in environment and economic cost (Babel and Kurniawan 2003; Singh and Prasad 2013a). Natural materials like farmyard manure (FYM) that are available in large quantities or certain waste products from industrial or agricultural operations such as saw dust and rice husk, etc. may have potential as inexpensive sorbents. Due to their low cost, these materials at end of their lifetime can be disposed of in agricultural fields for metal remediation purposes. The abundance and availability of agricultural by-products make it good sources of raw materials for natural sorbents. The organic substance present in the soil has a significant impact on absorption and translocation of heavy metal $(\mathrm{Cu}, \mathrm{Zn}, \mathrm{Pb}$ and $\mathrm{Cd})$ in soil and it turns into more stable forms and leads to accumulation of metals in organic horizons of soil and peat (Kabata-Pendias 2001). Angelova et al. (2010) have found that concentration of $\mathrm{Pb}$ and $\mathrm{Cu}$ decreased in potato peel and tubers with $10 \%$ compost or $10 \%$ vermicompost amendment in soil (Angelova et al. 2010). The removal and stabilization of metals can be done by using compost, biosolids and recycled paper waste (Jones and Healey 2010). Mineral amendments have been used in agriculture for remediation of heavy metal (Paulose et al. 2007). The mineral amendments can reduce the risk of exposure to humans or biota by reducing availability of metals to the soil, water or air (O'Day and Vlassopoulos 2010).

Other natural products such as saw dust and rice husk act as binding agent to reduce uptake of heavy metal from contaminated site (Nagh and Hanafiah 2008). Bio-availability of metal ions in soils is largely governed by chemical equilibrium of metal ions in solid and solution phases, adsorption reactions are important to determine availability of metal to plants and their mobility throughout the soil. Shubhan and Pradeep (2011) have shown that SD and $\mathrm{RH}$ act as biosorbent in hydroponic system and 
suggested that saw dust (SD) and rice husk (RH) could also be used to reduce metal availability. The appreciable reduction in availability of $\mathrm{Cd}$ in rice husk and saw dust amended soil is due to basic nature of complex compound: cellulose, hemicellulose, lignin, mineral ash containing large amount of $\mathrm{SiO}_{2}$ and tannins (containing hydroxyl groups). The lignin is known to interact with cations by exchanging with protons and subsequently by chelating with the metallic ions (Rafatullah et al. 2009). These organic components are actively involved in ion exchange. Lignin is the third major component of the wood cell wall and it is built up from the phenylpropane nucleus; an aromatic ring with a three carbon side chain, which is promptly available to interact with cationic metal ions (Fatemeh et al. 2008). Sidiras et al. (2013) have used autohydrolyzing Scots Pine (Pinus Sylvestris) sawdust for removing hexavalent chromium from water and wastewater media. Singh and Prasad (2013b) have also reported that application of natural products such as FYM, SD and RH in Cd-contaminated soil reduced the level of $\mathrm{Cd}$ by $36 \%$ under FYM, $23 \%$ under RH and $14 \%$ under SD amended soil.

To determine the chemical forms of $\mathrm{Cu}, \mathrm{Zn}, \mathrm{Ni}$ and $\mathrm{Cd}$ in fly ash stabilized sludge, sequential extraction method was used (Su and Wong 2003). The experiments have been performed in order to grow corn under greenhouse condition by amending the loamy acid soil with fly ash stabilized sludge. The result showed that sewage sludge amended with coal fly ash could reduce availability of $\mathrm{Cu}, \mathrm{Zn}, \mathrm{Ni}$ and $\mathrm{Cd}$ in sludge. With increasing rate of fly ash amendment, the DTPA extractable metals $(\mathrm{Cu}, \mathrm{Zn}, \mathrm{Ni}$, and $\mathrm{Cd})$ were reduced. The application of fly ash amended sludge also resulted into increase in dry mass of corn along with decrease in concentration of $\mathrm{Zn}$ and $\mathrm{Cu}$ in shoot tissues. Therefore, the amendment of fly ash in contaminated soil significantly reduced the availability of heavy metal by chemical modification of their chemical speciation into less available forms (Su and Wong 2003).

\section{By using nanotechnology}

The application of nanotechnology being mainly focused on animal science and medical research nanotechnology can also be applied to plant science research in order to analyze plant genomics and gene function as well as improvement of crop species (Monica and Cremonini 2009). The application of nanotechnology for remediation of contaminants may give promising results in the future. Nanotechnology can provide a way to purify the air and water resources by utilizing nanoparticles as a catalyst and/ or sensing systems (Fulekar et al. 2014). The search for new and advanced materials is an important task of contemporary research in the environmental protection. Yang et al. (2006) have found that application of nanostructured materials can be used as adsorbents or catalysts to remove toxic and harmful substances from wastewater and air and finally from soil. In order to understand possible benefits of applying nanotechnology to agriculture, the first step should be to analyze the level of penetration and transport of nanoparticles in plants. It is established that these particles tagged to agrochemicals or to other substances could reduce injury to plant tissues and amount of chemicals released into the environment. Some contact is, however, inescapable, due to the strong interaction of plants with soil growth substrates (Monica and Cremonini 2009). In the field of nanotechnology, production of nanomaterials and products containing them are rapidly developing fields, which provides many opportunities for new innovation. For the abatement of pollution, production in the field of nanotechnology is just a beginning. It can be explored to catalyze the important changes in the field of environment. The major factor which defines capability of nanoparticles as an extremely versatile remediation tool includes their very small particle sizes $(1-100 \mathrm{~nm})$ in comparison to a typical bacterial cell which has a diameter on the order of $1 \mu \mathrm{m}(1,000 \mathrm{~nm})$. Hence nanoparticles can be transported effectively by the groundwater flow. Despite their minuscule status, nanoscale particles may hold potential to costeffectively address some of the challenges of site remediation (Tina and Zhang 2003). Applications of nanotechnology in water treatment and purification have witnessed significant developments in recent years (Theron et al. 2008; Mauter and Elimelech 2008). However, little progress has been made regarding application of nanoparticles to improve agricultural soil quality and to reclaim drastically disturbed lands.

Liu and Zhao (2007) prepared and tested a new class of iron phosphate (vivianite) nanoparticles for in situ immobilization of $\mathrm{Pb}^{+2}$ in soils. Batch test results showed that the nanoparticles could effectively reduce the leachability and bioaccessibility of $\mathrm{Pb}^{+2}$ from soils. Liu (2011) also reported an effective remediation of a lead-laden soil from a shoot range using synthesized apatite nanoparticles. Salam (2013) have used multi-walled carbon nanotubes (CNTs) that were used successfully for the removal of Copper(II), Lead(II), Cadmium(II), and Zinc(II) from aqueous solution. Yu et al. (2013) also used CNTs and their composites to remove metals from contaminated water. These nanotubes attracted great attention due to their excellent adsorption performance. The removal efficiency for metal ions by CNTs was observed around 10-80\%, which could be improved to approach $100 \%$ by selectively functionalizing CNTs with organic ligands. Rathore et al. (2013) have found that the application of carbon nanoparticles resulted into 75-92\% reduction in Ni contamination from soil and about $99 \%$ reduction from water 
system. Carbon nanoparticle have exceptional adsorption and mechanical properties due to its unique electrical property, highly chemical stability and large specific surface area (Tofighy and Mohammad 2011; Salam 2013). The nanoparticles provided from Euphorbia macroclada plants were kept in experimental pots for 2 weeks and then the amount of their heavy metals were compared with that of the control pots. The data showed that concentrations of all the subjected metals decreased $(\mathrm{Pb}, 92 \%$; $\mathrm{Zn}, 76.05 \%$; $\mathrm{Cu}, 74.66 \%$; Cd, $69.08 \%$; Ni, $31.50 \%$ ) among which $\mathrm{Pb}$ showed the highest decrease. Nanoparticles of E. macroclada is suggested for removing and detoxification of heavy metals (especially $\mathrm{Pb}, \mathrm{Cd}, \mathrm{Cu}$ and $\mathrm{Zn}$ ), from polluted environments (Mohsenzadeh and Rad 2011). Similarly, Singh et al. (2013) have also used zero-valent iron nanoparticles for removing $\mathrm{Cr}$ from contaminated soil. They have reported about $99 \%$ removal of $\mathrm{Cr}$.

Strategies to reduce metal contamination from aquatic system

When wastewater is released to land without treatment, it leads to the accumulation of metals in the soil for years. Untreated wastewater contaminated with heavy metals is released into aquatic system. The micro-organisms and plants present in the contaminated aquatic system have ability to accumulate and magnify the level of heavy metals in their habitats. It may not only affect productivity and reproductive capacities of these organisms, but may also ultimately affect health of man (Davies et al. 2006). Higher levels of essential and non-essential metals are toxic to aquatic organisms as well as humans and it may potentially damage human physiological and biological systems (Fatoki et al. 2002). The heavy metal from aqueous solution can be removed by passive binding with nonliving biomass through biosorption process (Kumar and Oommen 2012). The technique of using micro-organism to reduce level of metal contamination is better than conventional separation techniques because of reusability of biomaterial, low operating cost and improved selectivity for specific metals of interest and short operation time (Srinath et al. 2002). The biosorption process is a new technology, which can easily use as a refining treatment in shallow bodies of water (Nirmal Kumar et al. 2006).

The dried, non-living, or pretreated microbial biomass frequently displays a higher affinity for metal ions compared with living one and seems to be a preferred alternative use of living cells in industrial applications for the removal of heavy metal ions from wastewaters. Living cells are likely to be more sensitive to metal ion concentration and adverse operating conditions of $\mathrm{pH}$ and temperature. The extent of metal binding is dependent on metal chemistry, nature of binding and metal affinity for binding sites on the cell surface. Furthermore, a constant nutrient supply is required for using living cells. Recovery of metals and regeneration of biosorbent is complicated for living cells. Higher affinity of non-living cells for metal ions compared with living one probably due to the absence of competing protons produced during metabolism (Das et al. 2007).

Heavy metal removal from aquatic system by algae includes sedimentation, flocculation, absorption and cations and anion exchange, complexation, precipitation, oxidation/reduction, microbiological activity and uptake. Microalgae remove heavy metals directly from polluted water by two major mechanisms: the first is a metabolismdependent uptake into their cells at low concentrations and the second is biosorption which is a non-active adsorption process (Mitra et al. 2012).

The algae have many features that make them ideal candidates for selective removal and concentration of heavy metals, which include high tolerance to heavy metals, ability to grow both autotrophically and heterotrophically, large surface area/volume ratios, phototaxy, phytochelatin expression and potential for genetic manipulation. The ability of macroalgae to accumulate metals within their tissues has led to their widespread use as biomonitors of metal availability in marine systems. Therefore, Chlorophyta and Cyanophyta are hyperabsorbents and hyperaccumulators for Arsenic and Boron, absorbing and accumulating these elements from their environment into their bodies. These algae can be hyperphytoremediators and their presence in water reduces water arsenic and boron pollutant (Chekroun and Baghour 2013). Some algal species may convert mercuric or phenylmercuric ions into metallic mercury which is then volatilized out of cell and from the solution. The blue green algae Phormidium successfully can hyperaccumulate heavy metals like $\mathrm{Cd}, \mathrm{Zn}, \mathrm{Pb}, \mathrm{Ni}$ and $\mathrm{Cu}$ (Chekroun and Baghour 2013). Caulerpa racemosa var. cylindracea as a low-cost biomaterial could be used for the removal of boron species from aqueous solution (Bursali et al. 2009).

Strategies to reduce metal contamination

from agricultural land system

\section{By using naturally grown hyperaccumulator plants}

Plants can be used to remove, transfer and stabilize heavy metals from contaminated soils (Jadia and Fulekar 2009; Garbisu et al. 2002). Phytoaccumulator plants have more tendencies to accumulate metals in their shoots and high tolerance to heavy metals (Baker et al. 2000). On the other hand, many hyperaccumulator plants tend to be slow growing and produce low biomass. Phytoremediation is the use of special type of plants to decontaminate soil or water by inactivating metals in the rhizosphere or translocating 
them in their aerial parts. The families like Asteraceae, Brassicaceae, Caryophyllaceae, Cyperaceae, Cunouniaceae, Fabaceae, Flacourtiaceae, Lamiaceae, Poaceae, Violaceae and Euphorbiaceae showed remediation property (Sarma 2011). Phytoremediation is a promising technology using plants and microbes to clean up contaminated air, soil and water (Behera 2014). To reduce the level of metal from polluted soil by these techniques are cheaper, efficient and a more environment friendly (Lone et al. 2008; Jing et al. 2007). Through phytoremediation technique, the metals are extracted or inactivated from the soil (Lombi et al. 2001; Bennett et al. 2003). It was reported that high concentration of $\mathrm{Cd}$ and $\mathrm{Ni}$ is accumulated by Sedum alfredii and Alyssum bertolonii, respectively (Deng et al. 2007; Kramer 2010). The ratio of metals between soil and plants parts should be more than one for phytoremediating species (Barman et al. 2000). The roots of Indian mustard are effective in removal of $\mathrm{Cd}, \mathrm{Cr}, \mathrm{Cu}, \mathrm{Ni}, \mathrm{Pb}$ and $\mathrm{Zn}$ (Prasad and Freitas 2003). There are different categories of phytoremediation which includes: phytoextraction, phytofiltration, phytostabilisation and phytovolatisation.

Phytoextraction involves the use of plants that has ability to extract the heavy metal from contaminated lands. As compared to the conventional techniques cost involved in phytoextraction would be more than ten times less per hectare (Salt et al. 1995). The level of metal contaminants can be reduced by the successive cropping and harvesting of phytoextracting plants (Vandenhove et al. 2001). Brassica napus is selected as major plant for accumulating high concentration of $\mathrm{Cd}$, and $\mathrm{Pb}, \mathrm{Zn}$ and $\mathrm{Cd}$ was accumulated more in Andrographis Paniculata (Selvam and Wong 2008; Tang et al. 2009). The plant Amaranthus retroflexus, B. juncea and Phaseolus acutifolius were found to most effective for extracting ${ }^{137} \mathrm{Cs}$ and ${ }^{90} \mathrm{Sr}$ (Fuhrmann et al. 2002). Lee et al. (2002) have reported that plutonium is accumulated ten times higher in Indian mustard (B. juncea) than sunflower (Helianthus annuus) grown in hydroponic media. Wuana and Okieimen (2010) have found that Zea mays (maize) is able to phytoextract the metals from contaminated soils. For recovery of metals from phytoremediating plants, the shoot biomasses are harvested for proper disposal in special site or are burnt (Islam et al. 2007).

For reducing the metal contamination from tannery waste contaminated site, the Sesamum indicum L. var. T55 (sesame) was used by Gupta and Sinha (2006). The trend of metal accumulation showed that it was highest for $\mathrm{K}$ followed by $\mathrm{Na}>\mathrm{Fe}>\mathrm{Zn}>\mathrm{Cr}>\mathrm{Mn}>\mathrm{Cu}>\mathrm{Pb}>$ $\mathrm{Ni}>\mathrm{Cd}$. The soil quality can be maintained by phytoextraction method. Jiang et al. (2010) have shown that quality of soil is maintained by using successive cropping of hyperaccumulator plant Sedum plumbizincicola for twoyear period. The physico-chemical properties (microbial biomass, basal respiration and enzymatic activities) of soil increased in the soil, where hyperaccumulator plant is grown (Jiang et al. 2010).

Jing et al. (2007) have shown that from aqueous solution, the metal can be removed by phytofiltration technique. It involves the use of plants to absorb, concentrate or precipitate metals. Both terrestrial as well as aquatic plants can be used for this technique (Jadia and Fulekar 2009). Ensley (2000) have found that only lower contamination from groundwater, surface water and wastewater can be removed by rhizofiltration. The plants that can be used for removing the metal through rhizofiltration are sunflower, Indian mustard, tobacco, rye, spinach, and corn, which are able to remove lead from water (Jadia and Fulekar 2009). The fibrous and much longer root present in the terrestrial plants are responsible for increasing remediation property of these kinds of plants (Raskin and Ensley 2000).

Phytostabilization technique is based on the use of plants to reduce mobility of heavy metal through absorption and precipitation by plants, thus reducing their bio-availability (Bennett et al. 2003; Jing et al. 2007). Whereas in case of volatilization, plants are used to absorb contaminants from the soil and transferred it into volatile forms and finally into the atmosphere through transpiration process (United States Environmental Protection Agency 2000).

The characteristics of plants involved in stabilization of heavy metals are that it should decrease the amount of water percolating through soil matrix. It acts as a barrier to prevent direct contact with contaminated soil and it should also prevent soil erosion and distribution of the toxic metal to other areas (Raskin and Ensley 2000). Jadia and Fulekar (2008) have observed that due to large surface area of fibrous roots of sorghum and intensive penetration of roots into the soil, it reduces leaching via stabilization of soil and capable of immobilizing and concentrating heavy metals in the roots. Heavy metals were efficiently absorbed by roots of sorghum plant at all concentration of 5, 10, 20, 40 and $50 \mathrm{mg} \mathrm{kg}^{-1}$ used and order of uptake of heavy metals was $\mathrm{Zn}>\mathrm{Cu}>\mathrm{Cd}>\mathrm{Ni}>\mathrm{Pb}$ (Jadia and Fulekar 2008). For volatilization process, a laboratory experiment was performed with tobacco (Nicotiana tabacum) and a small model plant (Arabidopsis thaliana). In genetically modified plants, a gene for mercuric reductase converted ionic mercury $(\mathrm{Hg}(\mathrm{II}))$ to less toxic metallic mercury ( $\mathrm{Hg}(0)$ ) and volatilized it (Meagher et al. 2000).

There are various biotechnological approaches for remediation of metal that include biomineralization (mineral synthesis by living organisms or biomaterials), biosorption (dead microbial and renewable agricultural biomass), phytostabilization (immobilization in plant roots), hyperaccumulation (exceptional metal concentration in plant shoots), dendroremediation (growing trees in polluted soils), biostimulation (stimulating living microbial population), rhizoremediation (plant and microbe), 


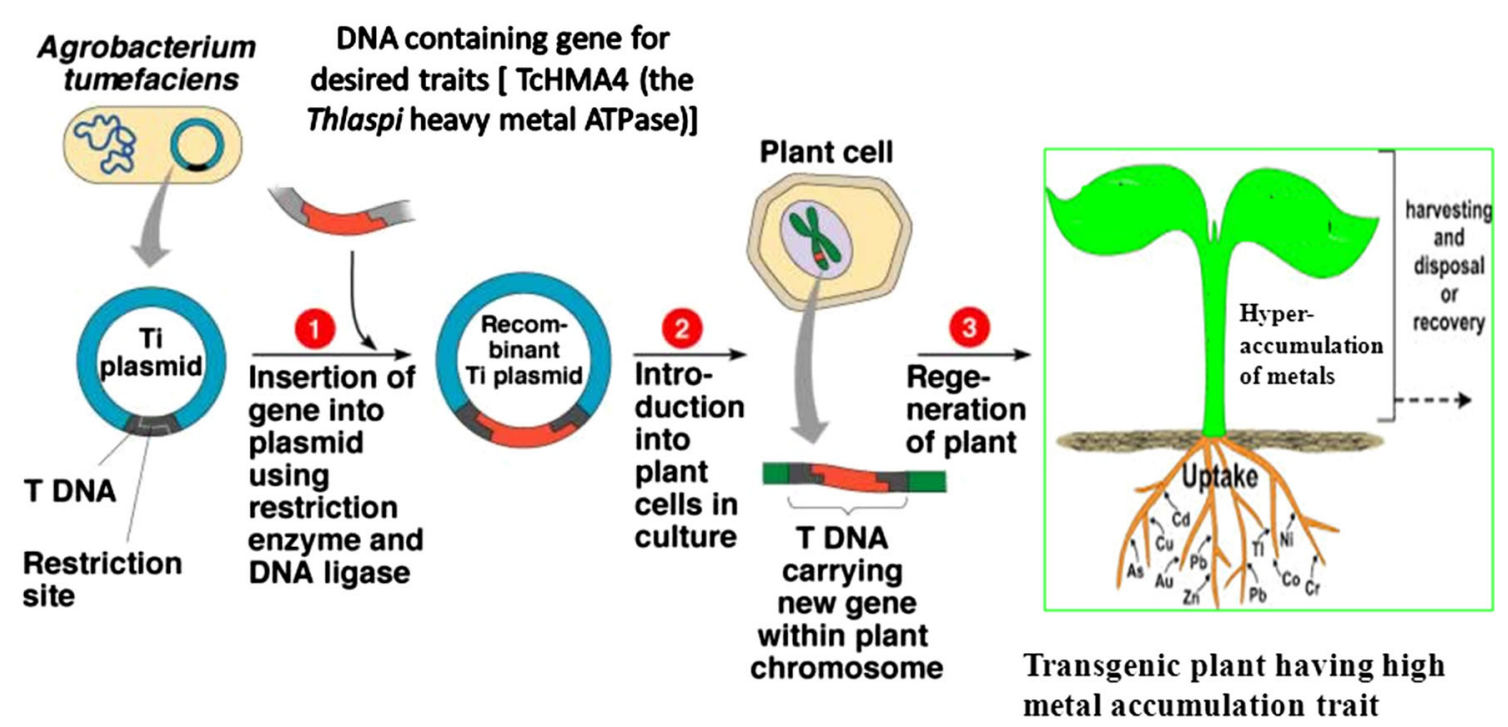

Fig. 2 A diagram to show application of genetically modified plants in heavy metal management

mycoremediation (stimulating living fungi/mycelial ultrafiltration), cyanoremediation (stimulating algal mass for remediation) and genoremediation (stimulating gene for remediation process). To clean the environment, cooperation, integration and assimilation of such biotechnological advances are required (Mani and Kumar 2013).

\section{By using biotechnologically modified plants}

Biotechnological tools include genetic engineering in order to improve the performance of plants in effective removal of metals from environment. With the help of this technique, overall functioning of plants can be altered. Addition of new genotype and phenotype by transferring the gene from metal-hyperaccumulating plants and microbes increases the remediation property of plants (James and Strand 2009). Aken (2008) has observed that transgenic plants can be safer for phytoremediation purpose. Isolation of quantitative trait loci (QTL) associated with tolerance of $\mathrm{Zn}$ metal in Arabidopsis halleri can be used for identifying the main genes responsible for adaptation against the metal stress (Nancy et al. 2007). When the bacterial merAB operon was transferred to the chloroplast genome of tobacco plant, then the plants showed more resistant toward highly toxic organic mercury (Heaton et al. 2005). To transfer the gene first DNA or gene of interest is spliced into a small, circular carrier DNA molecule which is known as a vector. After that the vector is introduced into plant cells either by physical means or biological means. When the foreign gene is entered into cell and integrated into the plant chromosome, the desired gene is "expressed" in a subset of the cells; these cells are selected in tissue culture and used to regenerate whole plants for subsequent breeding.
The extremely high level of Cd tolerance and hyperaccumulation in yeast is due to the presence of partial peptides from the C terminus of the TcHMA4 (the Thlaspi heavy metal ATPase) protein, which contains numerous possible His and Cys repeats residues for heavy metal binding. So this gene can be used for enhancing metal tolerance and phytoremediation potential of higher plants via expression of TcHMA4 (Fig. 2). It has great potential in metal remediation studies (Papoyan and Kochian 2004). Thomas et al. (2003) have show that transgenic plants expressing metallothioneins exhibited enhanced tolerance to high metal concentrations. To increase metal uptake, the yeast metallothionein CUP1 was introduced into tobacco plants, and this gene is expressed in plants. Expression of these genes increases phytoextraction of $\mathrm{Cu}$ and $\mathrm{Cd}$. By integrating dehaloperoxidase gene from salt marsh worm (Amphitrite ornata) into Arabidopsis and tobacco model systems, there was an enhancement in remediation property of experimental plants (Czako et al. 2006).

To remediate the methylmercury pollution, the tobacco plant was genetically modified by integrating a bacterial mer $B$ gene. The genetically modified tobacco callus showed more resistance to methylmercury $\left(\mathrm{CH}_{3} \mathrm{Hg}^{+}\right)$. It accumulates more mercury from $\mathrm{CH}_{3} \mathrm{Hg}^{+}$-containing medium than the wild-type. The merB gene encoded the MerB enzyme that degraded the $\mathrm{CH}_{3} \mathrm{Hg}^{+}$to $\mathrm{Hg}^{2+}$. After that it was accumulated in the form of less toxic Hg-polyP complex in the tobacco cells (Nagata et al. 2010).

\section{By using micro-organisms}

This remediation strategy includes application of microorganisms. Bioremediation has been regarded as an environment-friendly, inexpensive and efficient means of 
environmental restoration (Hrynkiewicz and Baum 2014). The role of micro-organisms is indirect as they support the growth of phytoaccumulator plants thus they help in the remediation of heavy metal (Yan-de et al. 2007; Zhuang et al. 2007). The micro-organisms, which are closely associated with roots, have been termed plant growthpromoting rhizobacteria (PGPR). Plant growth-promoting rhizobacteria include a diverse group of free-living soil bacteria that can improve host plant growth and development in heavy metal contaminated soils by mitigating toxic effects of heavy metals on plants. The association of plant growth-promoting bacteria with plant roots may exert beneficial effects on plant growth and nutrition by $\mathrm{N}_{2}$ fixation, production of phytohormones and siderophores, and transformation of nutrient elements (Koo and Cho 2009). In mine tailings areas contaminated with heavy metal to increase growth of plant the PGPR are introduced to seeds of Atriplex lentiformis and Buchloe dactyloides at sowing stage (Grandlic et al. 2009). With improvement the growth and yield of the Cicer arietinum, Vigna radiata and Pisum sativum, metal toxicity is also decreased with the help of PGPR (Gupta et al. 2004; Wani et al. 2007, 2008). With the help of PGPR the increase in the growth and reduction in the metal toxicity is due to enhancement in soil nutrient so it is one of the most suitable choices for bioremediation (Zaidi et al. 2003; Khan et al. 2009). Heshmatpure and Rad (2012) have also observed that the Pseudomonas fluorescence plant growth-promoting rhizobacterium increases the resistance against high levels of $\mathrm{Cd}$ and reduces its adverse effect in canola (B. napus L.) plant. This rhizobacterium enhances the efficiency of phytoremediation in the presence of Cd. Kanmani et al. (2012) have also found that microbes, especially bacteria capable of Chromium (VI) reduction, belonging to a heterogeneous group. They exhibit plasmid-mediated chromate resistance and the reduction in $\mathrm{Cr}$ is enzymatically mediated.

\section{Conclusion}

Increasing public awareness of environmental pollution influences search and development of technologies that help in cleanup of contaminants such as heavy metals. Heavy metal contamination of ecosystem is a major environmental concern. In order to reduce the level of metal contamination, several remediation technologies have been implemented. These techniques include immobilization methods with the help of low-cost absorbent, application of some chelating agent and biology-based technique, i.e., phytoremediation. The techniques at the level of molecular and nanotechnology are also used to enhance remediation properties and open up new possibilities for metal remediation technique. The aim of all the remediation technology should be linked with agricultural production, food security and scale down land tenure problems. Among all techniques, an alternative and eco-friendly remediation technology should be promoted in the developed and particularly developing countries, where heavy metal contamination is a serious problem with pace of population explosion and human developmental activities.

Acknowledgments Authors acknowledge the University of Allahabad for providing research facility, and they would like to thank UGC, India for providing grants to Dr Anita Singh as UGC-Dr D.S. Kothari Post Doctoral Fellow. The authors are also thankful to the Head, Department of Botany, University of Allahabad, Allahabad for providing necessary laboratory facilities during research work.

\section{References}

Adamu H, Uzairu A, Harrison GFS (2013) Assessment of trace metals in sewage water and sludge from River Kubanni drainage basin. Afr J Biotechnol 12(1):49-55

Agarwal A, Joshi H (2010) Application of nanotechnology in the remediation of contaminated groundwater: a short review. Recent Res Sci Technol 2(6):51-57

Aken BV (2008) Transgenic plants for phytoremediation: helping nature to clean up environmental pollution. Trends Biotechnol 26(5):225-227

Angelova VA, Radka Ivanova B, Galina Pevicharova C, Krasimir I (2010) Effect of organic amendments on heavy metals uptake by potato plants. In: 19th World congress of soil science, soil solutions for a changing world, 1-6 August 2010, Brisbane, Australia. Published on DVD

Arvas O, Keskin B, Yilmaz IH (2013) Effect of sewage sludge on metal content of grassland soil and herbage in semiarid lands. Turk J Agric For 37:1-9

Babel S, Kurniawan TA (2003) Low-cost adsorbents for heavy metals uptake from contaminated water: a review. J Hazard Mate 97:219-243

Baker AJM, McGrath SP, Reeves RD, Smith JAC (2000) Metal hyperaccumulator plants: a review of the ecology and physiology of a biological resource for phytoremediation of metalpolluted soils. In: Terry N, Banuelos G (eds) Phytoremediation of contaminated soil and water. Lewis Publishers, Boca Raton, pp $85-107$

Barman SC, Sahu RK, Bhargava SK, Chaterje C (2000) Distribution of heavy metals in wheat, mustard and weed grown in field irrigated with industrial. Bull Environ Contam Toxicol 64:489-496

Behera KK (2014) Phytoremediation, transgenic plants and microbes. Sustain Agri Rev 13:65-85

Bennett LE, Burkhead JL, Hale KL, Terry N, Pilon M, Pilon-smits EAH (2003) Bioremediation and biodegradation: analysis of transgenic Indian mustard plant for phytoremediation of heavy metal contaminated mine tailings. J Environ Qual 32:432-440

Bursali EA, Cavas L, Seki Y, Bozkurt SS, Yurdakoc M (2009) Sorption of boron by invasive marine seaweed: Caulerpa racemosa var. cylindracea. Chem Eng J 150:385

Cairns J, Smith EP, Orvos D (1988) The problem of validating simulation of hazardous exposure in natural systems. In: Barnett CC, Holms WM (eds) Proceedings of the 1988 Summer computer conference. The Society for Computer Simulation International, San Diego, pp 448-454

Central Pollution Control Board (CPCB) (2011) Hazardous metals and mineral pollution in India. A position paper, Indian National Science Academy New Delhi 
Chekroun KB, Baghour M (2013) The role of algae in phytoremediation of heavy metals: a review. J Mater Environ Sci 4(6):873-880

Czako M, Feng X, He Y, Liang D, Pollock R, Marton L (2006) Phytoremediation with transgenic plants. Acta Hortic 725:753-770

Das N, Charumathi D, Vimala R (2007) Effect of pretreatment on $\mathrm{Cd}^{2+}$ biosorption by mycelial biomass of Pleurotus florida. Afri J Biotechnol 6(22):2555-2558

Davies OA, Allision ME, Uyi HS (2006) Bioaccumulation of heavy metals in water, sediment and Periwinkle from Elechi Creek, Niger Delta. Afr J Biotechnol 5(10):933-968

Dede G, Ozdemir S, Hulusi Dede O (2012) Effect of soil amendments on phytoextraction potential of Brassica juncea growing on sewage sludge. Int J Environ Sci Technol 9(3):559-564

Deng DM, Shu WS, Zhang J, Zou HL, Ye ZH, Wong MH, Lin Z (2007) Zinc and cadmium accumulation and tolerance in populations of Sedum alfredii. Environ Pollut 147:381-386

Ensley BD (2000) Rationale for the use of phytoremediation. Phytoremediation of toxic metals: using plants to clean-up the environment. Wiley, New York. Environ Pollut 146:19-24

Evangelou MWH, Ebel M, Schaeffer A (2007) Chelate assisted phytoextraction of heavy metals from soils. Effect, mechanism, toxicity, and fate of chelating agents. Chemosphere 68:989-1003

Farouk S, Mosa AA, Taha AA, Ibrahim HM, Gahmery AE (2011) Protective effect of humic acid and chitosan on radish (Raphanus sativus, L. var. sativus) plants subjected to cadmium Stress. J Stress Physiol Biochem 7(2):99-116

Fasaei RG (2012) Malic acid and phosphorus influences on nickel phytoremediation efficiency and metal nutrients relationships in a Ni-polluted calcareous soil. Int Res J Appl Basic Sci 3(S):2805-2808

Fatemeh A, Shariatmadari H, Mirghaffari N (2008) Modification of rice hull and sawdust sorptive characteristics for remove heavy metals from synthetic solutions and wastewater. J Hazard Mater $154: 451-458$

Fatoki OS, Lujizan O, Ogunfowokan AO (2002) Trace metal pollution in Umata River. Water Res 28(2):183-189

Fuhrmann M, Lasat MM, Ebbs SD, Kochian LV, Cornish J (2002) Uptake of cesium-137 and strontium-90 from contaminated soil by three plant species; application to phytoremediation. J Environ Qual 31(3):904-909

Fulekar MH, Pathak B, Kale R K (2014) Nanotechnology: perspective for environmental sustainability. Environ Sustain Develop 12:87-114

Garbisu C, Hernandez-Allica J, Barrutia O, Alkorta I, Becerril JM (2002) Phytoremediation: a technology using green plants to remove contaminants from polluted areas. Rev Environ Health 17(3): 173-188

Govil PK, Reddy GLN, Krishna AK (2001) Contamination of soil due to heavy metals in the Patancheru industrial development area, Andhra Pradesh, India. Environ Geo 41:461-469

Grandlic CG, Palmer MW, Maier RM (2009) Optimization of plant growth-promoting bacteria-assisted phytostabilization of mine tailings. Soil Biol Biochem 41:1734-1740

Guo G, Zhou Q, Ma LQ (2006) Availability and assessment of fixing additives for the in situ remediation of heavy metal contaminated soils: a review. Environ Monit Assess 116:513-528

Gupta AK, Sinha S (2006) Chemical fractionation and heavy metals accumulation in the plants of Sesamum indicum (L.) var. T55 grown on soil amended with tannery sludge: selection of single extractants. Chemosphere 64:161-173

Gupta DK, Rai UN, Sinha S, Tripathi RD, Nautiyal BD, Rai P, Inouhe M (2004) Role of Rhizobium (CA-1) inoculation in increasing growth and metal accumulation in Cicer arietinum L. growing under fly-ash stress condition. Bull Environ Contamin Toxicol 73:424-431
Harmanescu M, Alda LM, Bordean DM, Gogoasa I, Gergen I (2011) Heavy metals health risk assessment for population via consumption of vegetables grown in old mining area; a case study: Banat County, Romania. Chem Central J 5:64

Heaton ACP, Rugh CL, Wang NJ, Meagher RB (2005) Physiological responses of transgenic merA-tobacco (Nicotiana tabacum) to foliar and root mercury exposure. Water Air Soil Pollut 161:137-155

Heshmatpure N, Rad MY (2012) The effect of PGPR (Plant-GrowthPromoting Rhizobacteria) on phytoremediation of cadmiums by canola (Brassica napus L.) cultivars of Hyola 401. Annals. Biol Res 3(12):5624-5630

Hiroaki I, Motoki I, Norie S, Ribeka T, Yoshio K, Shiro Y (2014) Dietary cadmium intake and breast cancer risk in Japanese women: a case-control study. J Hazard Mater 217:70-77

Hrynkiewicz K, Baum C (2014) Application of microorganisms in bioremediation of environment from heavy metals. In: Environmental Deterioration and Human Health, pp 215-227. doi:10. 1007/978-94-007-7890-0-9

Islam EU, Yang X, He Z, Mahmood Q (2007) Assessing potential dietary toxicity of heavy metals in selected vegetables and food crops. J Zhejiang Univ Sci B 8:1-13

Jadia CD, Fulekar MH (2008) Phytotoxicity and remediation of heavy metals by fibrous root grass (sorghum). J Appl Biosci 10:491-499

Jadia CD, Fulekar MH (2009) Phytoremediation of heavy metals: recent techniques. Afri J Biotechnol 8:921-928

James CA, Strand SE (2009) Phytoremediation of small organic contaminants using transgenic plants. Curr Opin Biotechnol 20(2):237-241

Jan FA, Ishaq M, Khan S, Shakirullah M, Asim SM, Ahmad I, Mabood F (2011) Bioaccumulation of metals in human blood in industrially contaminated area. J Environ Sci China 23(12):2069-2077

Javed M, Usmani N (2013) Assessment of heavy metals (Cu, Ni Co, $\mathrm{Fe}, \mathrm{Mn} \mathrm{Zn}$ ) pollution in effluent dominated rivulet water and their effect on glycogen metabolism and histology of Mastacembelus armatus. Springerplus 2:313-390

Jiang J, Wu L, Li N, Luo Y, Liu L, Zhao Q, Zhang L, Christie P (2010) Effects of multiple heavy metal contamination and repeated phytoextraction by Sedum plumbizincicola on soil microbial properties. Eur J Soil Biol 46(1):18-26

Jing Y, He Z, Yang X (2007) Role of soil rhizobacteria in phytoremediation of heavy metal contaminated soils. J Zhejiang Univ Sci B 8:192-207

John GF, Andrew B (2011) A lead isotopic study of the human bioaccessibility of lead in urban soils from Glasgow, Scotland. Sci Total Environ 409:4958-4965

Jolly YN, Islam A, Akbar S (2013) Transfer of metals from soil to vegetables and possible health risk assessment. SpringerPlus 2:385-393

Jones DL, Healey JR (2010) Organic amendments for remediation: putting waste to good use. Elements 6(6):369-374

Kabata-Pendias A (2001) Trace elements in soils and plants, 3rd edn. CRC Press LLC, Boca Raton

Kanmani P, Aravind J, Preston D (2012) Remediation of chromium contaminants using bacteria. Int $\mathrm{J}$ Environ Sci Technol 9(1):183-193

Kapungwe EM (2013) Heavy metal contaminated water, soils and crops in peri urban wastewater irrigation farming in Mufulira and Kafue towns in Zambia. J. Geogr Geol 5(2):55-72

Karimi N, Ghaderian SM, Schat H (2013) Arsenic in soil and vegetation of a contaminated area. Int $\mathbf{J}$ Environ Sci Technol 10(4):743-752

Khan MS, Zaidi A, Wani PA, Oves M (2009) Role of plant growth promoting rhizobacteria in the remediation of metal contaminated soils. Environ Chem Lett 7:1-19 
Koo SY, Cho KS (2009) Isolation and characterization of a plant growth-promoting rhizobacterium Serratia sp. SY5. J Microbiol Biotechnol 19:1431-1438

Kramer U (2010) Metal hyperaccumulation in plants. Annu Rev Plant Biol 61:517-534

Krishna AK, Govil PK (2004) Heavy metal contamination of soil around Pali Industrial Area, Rajasthan, India. Environ Geo 47:38-44

Krishna AK, Govil PK (2007) Soil contamination due to heavy metals from an industrial area of Surat, Gujarat, Western India. Environ Monit Assess 124:263-275

Kumar NJI, Oommen C (2012) Removal of heavy metals by biosorption using freshwater alga Spirogyra hyaline. J Environ Biol 33:27-31

Kupper H, Kochian LV (2010) Transcriptional regulation of metal transport gene and mineral nutrition during acclimatization to cadmium and zinc in the $\mathrm{Cd} / \mathrm{Zn}$ hyperaccumulator Thlaspi caerulescens (Ganges population). New Phytol 185:114-129

Lee JH, Hossner LR, Attrep MJ, Kung KS (2002) Uptake and translocation of plutonium in two plant species using hydroponics. Environ Pollut 117:61-68

Lin HJ, Sunge T, Cheng CY, Guo HR (2013) Arsenic levels in drinking water and mortality of liver cancer in Taiwan. J Hazard Mater 262:1132-1138

Liu R (2011) In-situ lead remediation in a shoot-range soil using stabilized apatite nanoparticles. In: Proceedings of the 85th ACS Colloid and Surface Science Symposium, McGill University, Montreal, Canada

Liu R, Zhao D (2007) Reducing leachability and bioaccessibility of lead in soils using a new class of stabilized iron phosphate nanoparticles. Water Res 41(12):2491-2502

Liu X, Song Q, Tang Y, Li W, Xu J, Wu J, Wang F, Brookes PC (2013) Human health risk assessment of heavy metals in soilvegetable system: a multi-medium analysis. Sci Total Environ 463:530-540

Lokeshwari H, Chandrappa GT (2006) Impact of heavy metal contamination of Bellandur Lake on soil and cultivated vegetation. Curr Sci 91(5):622-628

Lombi E, Zhao FJ, Dunham SJ, McGrath SP (2001) Phytoremediation of heavy metal-contaminated soils: natural hyperaccumulator versus chemically enhanced phytoextraction. J Environ Qual 30:1919-1926

Lone MI, He Z, Stoffella PJ, Yang X (2008) Phytoremediation of heavy metal polluted soils and water: progress and perspectives. J Zhejiang Univ Sci B 9:210-220

Luo C, Shen Z, Li X (2005) Enhanced phytoextraction of $\mathrm{Cu}, \mathrm{Pb}, \mathrm{Zn}$ and Cd with EDTA and EDDS. Chemosphere 59:1-11

Luo CL, Shen ZG, Li XD (2007) Plant uptake and the leaching of metals during the hot EDDS-enhanced phytoextraction process. Int J Phytoreme 9:181-196

Mani D, Kumar C (2013) Biotechnological advances in bioremediation of heavy metals contaminated ecosystems: an overview with special reference to Phytoremediation. Int J Environ Sci Technol. doi:10.1007/s13762-013-0299-8

Mauter MS, Elimelech M (2008) Environmental applications of carbonbased nanomaterials. Environ Sci Technol 42(16):5843-5859

Meagher RB, Rugh CL, Kandasamy MK, Gragson G, Wang NJ (2000) Engineered phytoremediation of mercury pollution in soil and water using bacterial genes. In: Terry N, Banuelos G (eds) Phytoremediation of contaminated soil and water. Lewis Publishers, Boca Raton, pp 201-219

Mitra N, Rezvan Z, Seyed Ahmad M, Hosein MGM (2012) Studies of water arsenic and boron pollutants and algae phytoremediation in three springs, Iran. Int J Ecosys 2(3):32-37

Mohsenzadeh F, Rad AC (2011) Application of nano-particles of Euphorbia Macroclada for bioremediation of heavy metal polluted environments. International Conference on Nanotechnology and Biosensors IPCBEE vol. 25

Monica BC, Cremonini R (2009) Nanoparticles and higher plants. Caryologia 62:161-165

Nagata T, Morita H, Akizawa T, Pan-Hou H (2010) Development of a transgenic tobacco plant for phytoremediation of methylmercury pollution. App Microbiol Biotechnol 87(2):781-786

Nagh WSW, Hanafiah MAKM (2008) Removal of heavy metal ions from wastewater by chemically modified plant wastes as adsorbents: a review. Bioresour Technol 99:3935-3948

Roosens NHCJ, Glenda W, Cécile G, Adeline C, Pierre SL (2007) The use of comparative genome analysis and synthetic relationships allows extrapolating the position of Zn tolerance QTL regions from Arabidopsis halleri into Arabidopsis thaliana. Trends Plant Sci 13(5):208-214

Nazemi S (2012) Concentration of heavy metal in edible vegetables widely consumed in Shahroud, the North East of Iran. J Appl Environ Biol Sci 2(8):386-391

Nedel-koska TV, Doran PM (2000) Hyper accumulation of cadmium by hairy roots of Thlaspi caerulescens. Biotechnol Bioeng 67:607-615

Kumar NJI, Hiren S, Kumar RN (2006) Biomonitoring of selected freshwater macrophytes to assess lake trace element contamination: a case study of Nal Sarovar Bird Sanctuary, Gujarat, India. J Limnol 65:9-16

Nogueira TA, Franco A, He Z, Braga VS, Firme LP, Abreu CH Jr (2013) Short-term usage of sewage sludge as organic fertilizer to sugarcane in a tropical soil bears little threat of heavy metal contamination. J Environ Manag 114:168-177

O'Day PA, Vlassopoulos D (2010) Mineral-based amendments for remediation. Elements 6(6):375-381

Onat B, Sahin UA, Akyuz T (2013) Elemental characterization of PM 2.5 and PM1 in dense traffic area in Istanbul, Turkey. Atmos Pollut Res 4:101-105

Ottosen LM, Jensen PE (2005) Electro-remediation of contaminated soil. In: Lens P, Grotenhuis T, Malina G, Tabak H (eds) Soil and sediment remediation. IWA Publishing, London, pp 264-287

Papoyan A, Kochian LV (2004) Identification of Thlaspi caerulescens genes that may be involved in heavy metal hyperaccumulation and tolerance characterization of a novel heavy metal transporting ATPase. Plant Physiol 136:3814-3823

Park RM, Bena JF, Stayner LT, Smith RJ, Gibb HJ, Lees PS (2004) Hexavalent chromium and lung cancer in the chromate industry: a quantitative risk assessment. Risk Anal 24(5):1099-1108

Paulose B, Datta SP, Rattan RK, Chhonkar PK (2007) Effect of amendments on the extractability, retention and plant uptake of metals on a sewage-irrigated soil. Environ Pollut 146(1):19-24

Prasad MNV, Freitas HMD (2003) Metal hyperaccumulation in plants-biodiversity prospecting for phytoremediation technology. Electron J Biotechnol 93(1):285-321

Rafatullah M, Sulaiman O, Hashim R, Ahmad A (2009) Adsorption of copper (II), chromium (III), nickel (II) and lead (II) ions from aqueous solutions by meranti sawdust. J Hazard Mater 170:969-977

Rahimi M, Farhadir R, Mehdizadeh R (2013) Phytoremediation: using plants to clean up contaminated soils with heavy metals. Int J Agri Res Rev 3(1):148-152

Rascio N, Navari-Izzo F (2011) Heavy metal hyperaccumulating plants: how and why do they do it? And what makes them so interesting? Plant Sci 180(2):169-181

Raskin I, Ensley BD (2000) Phytoremediation of toxic metals: using plants to clean up the environment. Wiley, New York

Rathore G, Adhikari T, Chopra N (2013) Management of nickel contaminated soil and water through the use of carbon nano particles. J chem Bio Phy Sci 3(2):901-905

Reinecke F, Groth T, Heise KP, Joentgen W, Müller N, Steinbüchel A (2000) Isolation and characterization of an Achromobacter 
xylosoxidans strain B3 and other bacteria capable to degrade the synthetic chelating agent iminodisuccinate. FEMS Microbiol Lett 188:41-46

Salam MA (2013) Removal of heavy metal ions from aqueous solutions with multi-walled carbon nanotubes: kinetic and thermodynamic studies. Int J Environ Sci Technol 10(4):677-688

Salt DE, Blaylock M, Kumar PBAN, Dushenkov V, Ensley BD, Chet I, Raskin I (1995) Phytoremediation: a novel strategy for the removal of toxic metal from the environment using plants. Biotechnol 13:468-474

Sarma H (2011) Metal hyperaccumulation in plants: a review focusing on phytoremediation technology. J Environ Sci Technol 4:118-138

Selvam A, Wong JW (2008) Phytochelatin synthesis and cadmium uptake of Brassica napus. Environ Technol 29:765-773

Sharma RK, Agrawal M, Marshall FM (2009) Heavy metals in vegetables collected from production and market sites of a tropical urban area of India. Food Chem Toxicol 47:583-591

Shubhan M, Pradeep DR (2011) Study to adsorbent of rice husk and saw dust (agriculture waste and timber waste). Int J Res Sci Technol 1:1-10

Sidiras D, Politi D, Batzias F, Boukos N (2013) Efficient removal of hexavalent chromium from aqueous solutions using autohydrolyzed Scots Pine (Pinus Sylvestris) sawdust as adsorbent. Int J Environ Sci Technol 10(6):1337-1348

Singh A, Prasad SM (2013a) Effect of agro-industrial waste amendment on Cd uptake in Amaranthus caudatus grown under contaminated soil: An oxidative biomarker response. Ecotoxicol Environ Saf. doi: 10.1016/j.ecoenv.2013.09.005i

Singh A, Prasad SM (2013b) Biometric characteristics and physiological response of Amaranthus caudatus grown in agricultural waste and fertiliser amended soil: a metal remediation approach. Environ Eng Manag J 12(10):1535-1545

Singh M, Müller G, Singh IB (2002) Heavy metals in freshly deposited stream sediments of rivers associated with urbanization of the Ganga Plain, India. Water Air Soil Pollut 141:35-54

Singh A, Sharma RK, Agrawal M, Marshall FM (2010) Health risk assessment of heavy metals via dietary intake of foodstuffs from the wastewater irrigated site of a dry tropical area of India. Food Chem Toxicol 48:611-619

Singh R, Gautam N, Mishra A, Gupta R (2011) Heavy metals and living systems: an overview. Indian J Pharmacol 43:246-253

Singh R, Mishra V, Singh RP (2013) Remediation of Cr(VI) contaminated soil by Zero-Valent Iron Nanoparticles (nZVI) entrapped in Calcium Alginate Beads. 2011 2nd International Conference on Environmental Science and Development IPCBEE vol 4

Srinath T, Verma TP, Ramteke W, Garg SK (2002) Chromium (VI) biosorption and bioaccumulation by chromate resistant bacteria. Chemosphere 48:427-435

Su DC, Wong JWC (2003) Chemical speciation and phytoavailability of $\mathrm{Zn}, \mathrm{Cu}, \mathrm{Ni}$ and $\mathrm{Cd}$ in soil amended with fly ash stabilized sewage sludge. Environ Int 29:895-900

Sukumara D, Kumar AA, Thanga SG (2012) Effect of chelating agents in phytoremediation of heavy metals. Adv Agric Sci Eng Res 2(9):364-372

Tahmasbian I, Nasrazadani A (2012) Soil electerokinetic remediation and its effects on soil microbial activity-a review. Afr J Microbiol Res 6(10):2233-2238

Tahmasbian I, Sinegani AAS (2013) Chelate-assisted phytoextraction of cadmium from a mine soil by negatively charged sunflower. Int J Environ Sci Technol. doi:10.1007/s13762-013-0394-x

Tandy S, Bossart K, Mueller R, Ritschel J, Hauser L, Schulin R, Nowack B (2004) Extraction of heavy metals from soils using biodegradable chelating agents. Environ Sci and Technol 38:937-944
Tang YT, Qiu RL, Zeng XW, Ying RR, Yu FM, Zhou XY (2009) Lead, zinc, cadmium hyperaccumulation and growth stimulation in Arabis paniculata. Franch Environ Exp Bot 66:126-134

Theron JJ, Walker A, Cloete TE (2008) Nanotechnology and water treatment: applications and emerging opportunities. Crit Rev Microbiol 34(1):43-69

Thomas JC, Davies EC, Malick FK, Endreszl C, Williams CR, Abbas M, Petrella S, Swisher K, Perron M, Edwards R, Ostenkowski P, Urbanczyk N, Wiesend WN, Murray KS (2003) Yeast metallothionein in transgenic tobacco promotes copper uptake from contaminated soils. Biotechnol Prog 19:273-280

Tina M, Zhang WX (2003) Environmental technologies at the nanoscale. Environ Sci and Technol 37(5):102A-108A

Tofighy MA, Mohammad T (2011) Adsorption of divalent heavy metal ions from water using carbon nanotube sheets. J Hazard Mater 185(1):140-147

United States Environmental Protection Agency (USEPA) (2000) Introduction to phytoremediation. EPA 600/R-99/107. U.S. environmental protection agency. Office of Research and Development, Washington DC. Pp 94

Vandenhove H, van Hees M, van Winkel S (2001) Feasibility of phytoextraction to clean up low-level uranium-contaminated soil. Int J Phytorem 3:301-320

Veschasit O, Meksumpun S, Meksumpun C (2012) Heavy metals contamination in water and aquatic plants in the Tha Chin River, Thailand. Kasetsart J (Nat Sci) 46:931-943

Wani PA, Khan MS, Zaidi A (2007) Cadmium, chromium and copper in green gram plants. Agron Sustain Dev 27:145-153

Wani PA, Khan MS, Zaidi A (2008) Effect of metal tolerant plant growth promoting Rhizobium on the performance of pea grown in metal amended soil. Arch Environ Contam Toxicol 55:33-42

Wilberforce JOO, Nwabue FI (2013) Heavy metals effect due to contamination of vegetables from Enyigba Lead Mine in Ebonyi State, Nigeria. Environ Pollut 2:19-26

Wuana RA, Okieimen FE (2010) Phytoremediation potential of maize (Zea mays L.). A review. Afr J Gen Agri 6(4):275-287

Wuana RA, Okieimen FE (2011) Heavy metals in contaminated soils: A review of sources, chemistry, risks and best available strategies for remediation. Int Scholarly Res Network ISRN Ecology, 1-20

Xiong W, Zhou YS, Mahjouri-Samani M, Yang WQ, Yi KJ, He XN, Liou SH, Lu YF (2009) Self-aligned growth of single-walled carbon nanotubes using optical near-field effects. Nanotechnol $20: 1-4$

Yan-de J, Zhen-li HE, Xiao-e Y (2007) Role of soil rhizobacteria in phytoremediation of heavy metal contaminated soils. J Zhejiang Univ Sci B 8(3):192-207

Yang K, Zhu LZ, Xing BS (2006) Adsorption of polycyclic aromatic hydrocarbons on carbon nonmaterials. Environ Sci Technol 40:1855-1860

Yu JG, Zhao XH, Yu LY, Jiao FP, Jiang JH, Chen XQ (2013) Removal, recovery and enrichment of metals from aqueous solutions using carbon nanotubes. J Radioanal Nuclear Chem. doi:10.1007/s10967-013-2818y

Zaidi A, Khan MS, Amil M (2003) Interactive effect of rhizotrophic microorganisms on yield and nutrient uptake of chickpea (Cicer arietinum L.). Eur J Agron 19:15-21

Zeid IM, Ghazi SM, Nabawy DM (2013) Alleviation of heavy metals toxicity in waste water used for plant irrigation. Int J Agro Plant Prod 4(5):976-983

Zhuang X, Chen J, Shim H, Bai Z (2007) New advances in plant growth-promoting rhizobacteria for bioremediation. Environ Int 33:406-413 